\title{
Cows' milk protein-sensitive enteropathy
}

\section{An important factor in prolonging diarrhoea of acute infective enteritis in early infancy}

\author{
N. IYNGKARAN, M. J. ROBINSON, E. SUMITHRAN, S. K. LAM, S. D. PUTHUCHEARY, AND \\ M. YADAV
}

From the Departments of Paediatrics, Pathology, Bacteriology, and Genetics and Cellular Biology, University of Malaya, Kuala Lumpur

SUMMARY The possible role of cows' milk protein in prolonging diarrhoea in very young infants with acute infective enteritis was studied in 14 infants, 9 under the age of 2 months and 5 older than 6 months. Bacterial pathogens were isolated from the stools of 4 infants from the younger age group. After appropriate initial treatment the infants were maintained on a cows' milk protein-free formula. 6 weeks later jejunal biopsies were performed before and 24 hours after challenge with a low lactose cows' milk protein formula. The immunoglobulin and complement levels in the serum and duodenal juice were also estimated at these times. Attempts to isolate bacterial and viral pathogens in stools were again made in all patients. The 5 older infants clinically tolerated cows' milk protein and their pre- and postchallenge jejunal biopsies were within normal limits. However, significant histological changes were observed in the postchallenge jejunal biopsies of all 9 infants under 2 months of age. In addition, 5 of these infants developed diarrhoea. This suggests that the jejunal mucosa of very young infants previously fed a cows' milk protein-based formula and who contract infective enteritis suffers damage when rechallenged with cows' milk protein.

There is general agreement that diarrhoea occurring in the first weeks of life is frequently prolonged and more hazardous than at any other period. The important factors responsible for this include the nature of the infection and the response of the young infant to infection, the frequency of sugar intolerance in young infants with infective enteritis (Burke et al., 1965; Lifshitz et al., 1971), dehydration and electrolyte imbalance which occur more rapidly in the smaller infant and which require great precision in the insertion, maintenance, and monitoring of intravenous infusions, and the prior nutritional status of the infant (Lifshitz et al., 1971).

We believe that feeding with a cows' milk proteinbased formula before the onset of acute infective enteritis is an additional factor in prolonging diarrhoea. Harrison et al. (1976) studied 25 children with cows' milk protein intolerance and have suggested that an acute attack of gastroenteritis, in damaging the small intestinal mucosa, may act as a triggering mechanism in cows' milk protein intolerance. Cows' milk protein-sensitive enteropathy has been suspected in the pathogenesis of intractable Received 5 July 1977 diarrhoea but objective proof has been lacking because satisfactory criteria for the diagnosis of cows' milk protein-sensitive enteropathy have not been available (Hyman et al., 1971; Shwachman et al., 1973). Recently Iyngkaran et al. (1978) proposed combined clinical and histological criteria for the diagnosis. We have applied these criteria in testing the following hypothesis put forward to explain the mechanisms involved-a small infant who contracts acute infective enteritis suffers damage and increased permeability of the gut mucosa by the aetiological agent. Gut permeability to cows' milk protein antigen may result in sensitisation so that a subsequent challenge with cows' milk protein may cause an immunological reaction on the gut wall resulting in additional mucosal damage, malabsorption, and continuing diarrhoea (Harrison et al., 1976). To test this hypothesis the following study was designed.

\section{Patients and methods}

Infants under the age of 2 months presenting with the clinical features of acute infective enteritis, admitted to the Department of Paediatrics, University Hospi- 
tal, between March and October 1976 were studied. All infants in this study had been fed a cows' milkbased formula before and up to the time of the episode of acute diarrhoea. Rehydration and correction of fluid and electrolyte imbalance were initially carried out intravenously. When the infant's condition improved and the diarrhoea was controlled, an oral $5 \%$ dextrose in $\frac{1}{b}$ isotonic saline mixture was offered. Those infants who tolerated this mixture were further studied for cows' milk protein-sensitive enteropathy. This required refeeding with a formula free of cows' milk protein, such as Pregestimil, Nutramigen, or Sobee. All infants were kept in hospital until the stools were normal, the infant was feeding well, and weight gains had started again. They were then discharged home, usually within 2 weeks of admission, the mothers being supplied with the appropriate formula free of cows' milk protein and instructed not to offer any other milk without consulting us. 6 weeks later the infants were admitted for further study.

Investigations at 6 weeks. (1) Low-lactose cows' milk provocation test. In the majority of the infants A1 110 (Nestle*) was used. In this test an initial feeding of $5 \mathrm{ml}$ was offered. If no reaction occurred, the volume was doubled hourly for the first 4 hours and subsequently 3 hourly until daily fluid requirements were met. (2) Haemoglobin, total and differential white cell count before and after the reintroduction of cows' milk. (3) Determination of complement and immunoglobulins in duodenal juice before and 24 hours after milk challenge. (4) Determination of serum complement $(\mathrm{C} 3, \mathrm{C} 4)$, serum immunoglobulins $\operatorname{IgA}, \operatorname{IgG}, \operatorname{IgM}$, and $\operatorname{IgE}$ at $0,1 \frac{1}{2}, 4,12$, and 24 hours after cows' milk challenge. (5) Testing of stools (if diarrhoea occurred) by the Clinitest method to exclude secondary sugar intolerance. (6) In all infants attempts were made to isolate parasitic, bacterial, and viral pathogens from the stools by culture, and by examination of stools under the light and electron microscope, 12 to 24 hours before and 12 to 24 hours after milk challenge. (7) Jejunal biopsy. The proximal jejunal biopsy specimen taken with the Watson paediatric capsule just distal to the duodenojejunal junction was examined under a dissecting microscope. Thereafter the specimen was divided into three portions, one fixed in glutaraldehyde for light and electron microscope studies, a second for enzyme determinations, and a third portion for immunofluorescence studies. In addition, a mucosal imprint was done to detect Giardia lamblia (Kamath and Murugasu, 1974). The following jejunal biopsies were performed: (a) prechallenge, and (b) postchallenge; this was performed 24 hours after the

$* 0.07 \%$ lactose after reconstitution. introduction of cows' milk irrespective of the presence or absence of symptoms.

\section{Results}

Fourteen infants were studied, 9 under 2 months of age and 5 over 6 months. The latter 5 infants clinically tolerated cows' milk and their pre- and postchallenge jejunal biopsies were within normal limits. Significant mucosal changes were, however, observed in the postchallenge compared to the prechallenge jejunal biopsies from all the 9 infants under 2 months. In addition, 5 of these 9 infants developed diarrhoea. In 4 infants bacterial pathogens were isolated from stools during their initial admission and were still present at the time of the challenge studies 6 weeks later. The clinical and histological data of the 9 infants are summarised in Tables 1 and 2. The results of the immunological studies will be reported in full later.

\section{Discussion}

The 9 infants studied were all below the age of 6 weeks and had made a complete clinical recovery from an episode of acute infective enteritis. A small bowel biopsy taken 6 weeks after clinical recovery showed either normal histology or changes regarded as only marginally abnormal. A further biopsy taken 24 hours after the reintroduction of a cows' milk formula (A1 110) showed mucosal damage in all 9 infants. In addition, 5 infants developed diarrhoea, 3 within 48 hours, and 2 at 1 week and 2 weeks respectively after challenge and while receiving a cows' milk-based formula. All 5 responded satisfactorily when cows' milk protein was excluded from their diets. It is our belief that the mucosal changes shown in these infants are the result of re-exposure to cows' milk protein.

In 4 of the infants bacterial pathogens were isolated from stools and were still present 6 weeks later despite clinical recovery (Table 2). However, it is extremely unlikely that the change of milk formula would have provoked bacterial activity and mucosal damage within 24 hours - the time interval between the two biopsies. Furthermore, in 5 infants bacterial pathogens were not isolated at any stage.

Sugar intolerance was carefully excluded as an aetiological factor at the onset of the study and was excluded throughout the recovery period by testing of stools for reducing substances using the method of Kerry and Anderson (1964). Reducing substances were found in the stools of one infant when the cows' milk-based formula was introduced. As the quantity of lactose contained in A1 110 is less than $0.07 \%$, it is unlikely that this small quantity of 
Table 1 Clinical profile of 9 infants with acute enteritis sensitive to cows' milk protein

\begin{tabular}{|c|c|c|c|c|c|c|c|c|c|c|c|}
\hline $\begin{array}{l}\text { Case } \\
\text { no. }\end{array}$ & $\begin{array}{l}\text { Age } \\
(d)\end{array}$ & $\operatorname{Sex}$ & $\begin{array}{l}\text { Ethnic } \\
\text { group }\end{array}$ & $\begin{array}{l}\text { Birthweight } \\
(\mathrm{kg})\end{array}$ & $\begin{array}{l}\text { Type of feed } \\
\text { since birth }\end{array}$ & $\begin{array}{l}\text { Age at } \\
\text { onset of } \\
\text { diarrhoea } \\
\text { (d) }\end{array}$ & $\begin{array}{l}\text { Duration } \\
\text { of } \\
\text { diarrhoea } \\
\text { (d) }\end{array}$ & $\begin{array}{l}\text { Stool } \\
\text { isolate* } \\
\text { (virus and } \\
\text { bacteria) }\end{array}$ & $\begin{array}{l}\text { Sugar } \\
\text { intolerance }\end{array}$ & $\begin{array}{l}\text { Milk feed at } \\
\text { discharge }\end{array}$ & $\begin{array}{l}\text { Duration } \\
\text { of illness } \\
\text { (d) }\end{array}$ \\
\hline $\begin{array}{l}1 \\
2 \\
3\end{array}$ & $\begin{array}{r}4 \\
8 \\
31\end{array}$ & $\begin{array}{l}\mathbf{M} \\
\mathbf{M} \\
\mathbf{M}\end{array}$ & $\begin{array}{l}\text { Chinese } \\
\text { Chinese } \\
\text { Indian }\end{array}$ & $\begin{array}{l}3 \cdot 03 \\
3 \cdot 5 \\
3 \cdot 85\end{array}$ & $\begin{array}{l}\text { CMF } \\
\text { CMF } \\
\text { Breast for } 1 \text { week; } \\
\text { CMF from } 1 \\
\text { week }\end{array}$ & $\begin{array}{r}3 \\
5 \\
29\end{array}$ & $\begin{array}{l}1 \\
3 \\
2\end{array}$ & $\begin{array}{l}\text { Neg } \\
\text { EPEC } \\
\text { Neg }\end{array}$ & $\begin{array}{c}\text { Neg } \\
\text { ", }\end{array}$ & $\begin{array}{l}\text { Sobee } \\
\text { Sobee } \\
\text { Nutramigen }\end{array}$ & $\begin{array}{l}14 \\
14 \\
10\end{array}$ \\
\hline 4 & 9 & $\mathbf{F}$ & Chinese & $3 \cdot 9$ & $\begin{array}{l}\text { Breast for } 6 \text { days; } \\
\text { CMF from } 6 \text { days }\end{array}$ & 6 & 3 & Neg & ", & Sobee & 2 \\
\hline $\begin{array}{l}5 \\
6 \\
7 \\
8 \\
9\end{array}$ & $\begin{array}{r}28 \\
9 \\
28 \\
9 \\
42\end{array}$ & $\begin{array}{l}\mathbf{F} \\
\mathbf{M} \\
\mathbf{F} \\
\mathbf{M} \\
\mathbf{M}\end{array}$ & $\begin{array}{l}\text { Chinese } \\
\text { Malay } \\
\text { Indian } \\
\text { Chinese } \\
\text { Chinese }\end{array}$ & $\begin{array}{l}2 \cdot 35 \\
3 \cdot 5 \\
2 \cdot 88 \\
3 \cdot 0 \\
3 \cdot 4\end{array}$ & $\begin{array}{c}\text { CMF } \\
\text { ", } \\
\text { ", } \\
\text { ", }\end{array}$ & $\begin{array}{r}3 \\
8 \\
25 \\
8 \\
28\end{array}$ & $\begin{array}{r}25 \\
1 \\
3 \\
1 \\
14\end{array}$ & $\begin{array}{l}\text { Salmonella } \\
\text { EPEC } \\
\text { Neg } \\
\text { Neg } \\
\text { Salmonella }\end{array}$ & $\begin{array}{l}\text { ", } \\
\text { ", } \\
\text { ", }\end{array}$ & $\begin{array}{c}", \\
", \\
\text { Pregestimil }\end{array}$ & $\begin{array}{r}28 \\
6 \\
3 \\
6 \\
10\end{array}$ \\
\hline
\end{tabular}

EPEC =enteropathogenic $E$. coli.

Table 2 Clinical symptoms, jejunal mucosal changes, and stool isolates before and after challenge with cows' milk protein in 9 infants with acute enteritis sensitive to cows' milk protein

\begin{tabular}{|c|c|c|c|c|c|c|c|c|c|c|}
\hline \multirow[b]{2}{*}{$\begin{array}{l}\text { Case } \\
\text { no. }\end{array}$} & \multicolumn{2}{|c|}{$\begin{array}{l}\text { Stool isolates* } \\
\text { at } 1 \text { st admission }\end{array}$} & \multicolumn{2}{|c|}{$\begin{array}{l}\text { Stool isolates } \\
12-24 \mathrm{~h} \text { prechallenge }\end{array}$} & \multicolumn{2}{|c|}{$\begin{array}{l}\text { Stool isolates } \\
12-24 \text { h postchallenge }\end{array}$} & \multicolumn{2}{|c|}{ Prechallenge } & \multicolumn{2}{|l|}{ Postchallenge } \\
\hline & Virus & Bacteria & Virus & Bacteria & Virus & Bacteria & Symptoms & $\begin{array}{l}\text { Histological } \dagger \\
\text { abnormality }\end{array}$ & Symptoms & $\begin{array}{l}\text { Histological } \dagger \\
\text { abnormality }\end{array}$ \\
\hline 1 & - & - & - & - & - & - & Nil & Normal (0) & $\begin{array}{l}\text { Diarrhoea } 7 \mathrm{~h} \text { after } \\
\text { challenge }\end{array}$ & Severe (13) \\
\hline 2 & - & EPEC & - & EPEC & - & EPEC & , , & Mild (4) & Nil & Moderate (11) \\
\hline 3 & - & - & - & - & 一 & - & $"$ & Normal (0) & $\begin{array}{l}\text { Diarrhoea, weight } \\
\text { loss, lethargy } 2 \mathrm{w} \\
\text { postchallenge }\end{array}$ & Moderate $(9 \cdot 5)$ \\
\hline 4 & - & - & - & - & - & - & ", & Normal (0) & $\begin{array}{l}\text { Diarrhoea } 48 \mathrm{~h} \\
\text { postchallenge }\end{array}$ & Moderate (9) \\
\hline 5 & 一 & Salmonella & - & Salmonella & - & Salmonella & ", & Mild (5.5) & $\begin{array}{l}\text { Diarrhoea, weight } \\
\text { loss } 1 \mathrm{w} \\
\text { postchallenge }\end{array}$ & Moderate (11) \\
\hline 6 & - & EPEC & - & EPEC & - & EPEC & ", & Normal (1) & Nil & Moderate (10) \\
\hline 7 & - & - & 一 & - & 一 & - & " & Normal (3) & $\begin{array}{l}\text { Vomiting, fever, } \\
\text { lethargy, diarrhoea, } \\
2 \text { h postchallenge }\end{array}$ & Severe (13) \\
\hline $\begin{array}{l}8 \\
9\end{array}$ & - & Salmonella & - & $\overline{\text { Salmonella }}$ & - & $\overline{\text { Salmonella }}$ & ", & $\begin{array}{l}\text { Normal (2) } \\
\text { Mild }(4 \cdot 5)\end{array}$ & $\begin{array}{l}\text { Nil } \\
\text { Nil }\end{array}$ & $\begin{array}{l}\text { Moderate (9) } \\
\text { Moderate (8) }\end{array}$ \\
\hline
\end{tabular}

* = negative.

†Figures in parentheses indicate scores: normal $<3$, mild abnormality 3-7, moderate abnormality 8-11, severe abnormality $>11$.

lactose would have produced the mucosal changes. In fact there is little or no evidence to suggest that lactose causes mucosal damage directly. It is much more likely that lactose intolerance had either persisted after the initial bowel infection or that it had occurred as the result of mucosal damage induced by the cows' milk protein present in the formula A1 110 (Liu et al., 1967).

On the basis of this limited study we suggest that small infants who have been fed a cows' milk formula before the onset of acute infective enteritis should be fed a non-cows' milk protein formula and this should be continued for some weeks after recovery. It is clear that further work is necessary to confirm these observations, and if confirmed, to establish the actual incidence. We have duplicated this study in a small group of 5 infants over the age of 6 months but could detect no evidence of either clinical disease or histological changes in the bowel mucosa. This further confirms our clinical experience that older infants tolerate cows' milk protein in the refeeding regimen after acute infective enteritis.

We are grateful to the nursing staff for their cooperation and to Mr P. Thirukumar for technical assistance; to Professor C. M. Anderson and Dr M. J. Tarlow from the Institute of Child Health, Birmingham, for valuable criticisms. This project was supported by funds from the Research Committee of the University of Malaya. Sobee, Pregestimil, and Nutramigen were donated by Mead Johnson. 


\section{References}

Burke, V., Kerry, K. R., and Anderson, C. M. (1965). The relationship of dietary lactose to refractory diarrhoea in infancy. Australian Paediatric Journal, 1, 147-160.

Harrison, M., Kilby, A., Walker-Smith, J. A., France, N. E. and Wood, C. B. S. (1976). Cows' milk protein intolerance; a possible association with gastroenteritis, lactose intolerance, and IgA deficiency. British Medical Journal, 1, 1501-1504.

Hyman, C. J., Reiter, J., Rodnan, J., and Drash, A. L. (1971). Parenteral and oral alimentation in the treatment of the non-specific protracted diarrhoeal syndrome in infancy. Journal of Pediatrics, 78, 17-29.

Iyngkaran, N., Robinson, M. J., Prathap, K., Sumithran, E., and Yadav, M. (1978). Cows' milk protein-sensitive enteropathy: combined clinical and histological criteria for diagnosis. Archives of Disease in Childhood, 53, 20-26.

Kamath, K. R., and Murugasu, M. (1974). A comparative study of four methods for detecting Giardia lamblia in children with diarrhoeal disease and malabsorption. Gastroenterology, 66, 16-21.

Kerry, K. R., and Anderson, C. M. (1964). A ward test for sugar in the faeces. Lancet, 1, 981-982.

Lifshitz, F., Coello-Ramirez, P., Gutierrez-Topete, G., and Cornado-Cornet, M. C. (1971). Carbohydrate intolerance in infants with diarrhoea. Journal of Pediatrics, 79, 760-767.

Liu, H.-Y., Tsao, M. U., Moore, B. A., and Giday, Z. (1968). Bovine milk protein-induced intestinal malabsorption of lactose and fat in infants. Gastroenterology, 54, 27-34.

Shwachman, H., Lloyd-Still, J. D., Khaw, K.-T., and Antonowicz, I. (1973). Protracted diarrhoea of infancy treated by intravenous alimentation. II. Studies of small intestinal biopsy results. American Journal of Diseases of Children, 125, 365-368.

Correspondence to Dr N. Iyngkaran, Department of Paediatrics, University Hospital, Kuala Lumpur, Malaysia. 